\title{
THE UNIVERSITY OF CALGARY AND THE UNIVERSITIES ACT: TELLING THE STORY OF PURPOSIVENESS
}

\author{
EUGENE E. DAIS
}

Departing from a conventional account of the history and events that culminated in the establishment of the University of Calgary, the author provides a purposive approach to the 1966 Universities Act. The author argues that as an enabling statute, the Act is an unfinishable legal fact. It exists as a framework to coordinate action to serve the public interest. As such, it calls for a complex purposive interpretation rooted in the theoretical underpinnings of moral legalism. Drawing on Dworkin's notion of interpretive integrity, the author demonstrates how ambiguities on the face of the Act can best be resolved by applying the principles of inclusive and pure integrity. The author's analysis reveals that the University of Calgary professoriat does not merely constitute a group of "scholarly servants", but rather a "company of scholars".
L'auteur s'écarte du compte rendu historique traditionnel des événements qui ont abouti à l'établissement de l'Université de Calgary et choisit de l'aborder sous l'angle de la Universities Act de 1966. L'auteur soutient que, en tant que loi d'habilitation est, l'Act est un fait légal impossible à achever. Elle existe en tant que structure destinée à coordonner les actions qui servent l'intérêt public. Elle exige donc une interprétation raisonnée complexe ancrée dans le fondement théorique du légalisme moral. Invoquant la notion d'intégrité d'interprétation selon Dworkin, l'auteur démontre comment il est possible de résoudre les ambiguïtés de la loi en appliquant les principes d'intégrité inclusive et pure. L'analyse de l'auteur révèle que le corps professoral de l'Université de Calgary ne constitue pas simplement un groupe d'remployés savants», mais plutôt une «compagnie de savants».

\section{TABLE OF CONTENTS}

I. INTRODUCTION $\ldots \ldots \ldots \ldots \ldots \ldots \ldots \ldots \ldots \ldots \ldots$

II. TELLING THE STORY OF

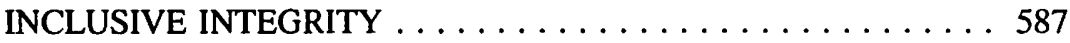

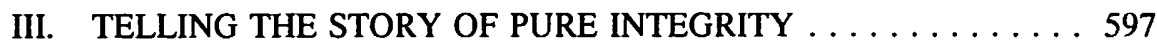

IV. CONCLUSION $\ldots \ldots \ldots \ldots \ldots \ldots \ldots \ldots \ldots \ldots \ldots \ldots \ldots \ldots$

\section{INTRODUCTION}

In this essay, I tell the story of the University of Calgary in a special way. I do not tell it in the usual way, as the history of people and events that in 1966 led to its establishment by the Universities Act. ${ }^{1}$ That story would relate the struggle of Calgarians to acquire the university they first sought in 1905 , the year Alberta became a province of Canada. As Calgarians recall it, Edmonton would have the provincial capital and Calgary, the provincial university. The promise, however, was only half kept. To be sure, at the time Edmonton did not get both, but Calgary got neither. ${ }^{2}$ The university was located in Strathcona just across the river from Edmonton and later to become a part of Edmonton.

Professor, Faculty of Law, the University of Calgary.

An Act Respecting Provincial Universities, S.A. 1966, c. 105. In 1980, it was re-enacted as the Universities Act, R.S.A. 1980, c. U-5 [hereinafter the Act or the 1966 Act or the 1966 Universities Act].

2 Calgarians in the legal profession add to the story that Calgary was thereafter promised the law school, but it later became part of the University of Alberta. In 1975, a law faculty was established at the University of Calgary. 
But, as interesting as that story would be, it would not answer the important question of just what Calgary did receive in 1966. We know it was an institution called a "university", but exactly what is a university?

In the obvious sense, this question hardly makes sense. The 1966 Act legalized what Calgarians had already obtained in 1965, namely the academic autonomy for the Calgary Branch of the University of Alberta. If asked what they received, Calgarians would simply have pointed to the people and buildings in northwest Calgary the Act legally named "The University of Calgary". This obvious sense, however, is misleading. A university, or any other institution, is not created merely by naming buildings with people added. To be sure, an institution must have people and buildings, but it cannot actually exist without also having a purpose peculiar to it, the sort of purpose that continuously coordinates action according to rules. A university, to be exact, is a set of rules governing the activity of certain people that serve the purpose peculiar to the idea of an institution of higher learning. That fact, we may say, is not a finished nor even a finishable natural fact; it is an unfinishable legal (or normative) fact, which manifests itself as if it had (unintended) purposiveness without (intended) purpose.

The story told here is the story of the peculiar purpose that makes a university a distinctive enterprise, and that without that purpose the Universities Act would be misnamed. To tell this kind of story, I must also discuss legal theory, mainly for two reasons. First, statutes are only part of what is law, and the Universities Act is the type of statute called an enabling statute. It is not a familiar type, for example, the types that punish crime, tax income or regulate traffic or business. Its purpose instead is to establish a constitution or framework to coordinate action, like that of a private corporation; but unlike it in that it is to serve the public, not the private, interest. Such statutes, those that serve an essential public interest of a free and democratic society, like higher education, call for a complex kind of purposive interpretation. Legal theory should make this point clear by clarifying what is meant by an unfinishable legal fact.

Second, lawyers and even judges naturally tend to resist purposive interpretation. Their specialized business is to determine rights and duties of parties to settle their disputes, and for this reason to interpret the meaning of statutes only insofar as they bear on such disputes. They are not in the business of reforming statutes, that is, of transforming their meaning so that they serve their purpose better or serve a better purpose. Their task, supposedly, is simply to follow the plain meaning of the rules statutes lay down. In fact, in a free and democratic society, judges have the duty to accept as plain legal fact any statute the legislature enacts, and not as they prefer it - unless, of course, the statute violates the Canadian Charter of Human Rights and Freedoms. ${ }^{3}$ Here, legal theory should make clear the paradox why in principle the plain fact outlook fails, although it may appear to succeed in most cases. 
The plain fact outlook of judges and practicing lawyers is summed up in the reigning legal theory called legal positivism. The chief purpose of legal positivism is to remove from the law all influence of purpose, and to reduce law strictly to a coercive instrument free of any version of legal moralism, even the legal moralism that the political majority would choose to keep society moral. Legal positivism purports to do this by separating "the law as it is" - as judges semantically find it - from any purpose of law whatsoever, or at least from any idea that law as a whole has purpose. ${ }^{4}$ Law is to be viewed, instead, strictly as the coercive instrument political government uses to control society by whatever public policies it chooses, moral or immoral. Law itself, or rather what judges say it is, cannot choose the purposes it is to implement. It is, in other words, neutral as to all versions of legal moralisms. This means that judges must interpret statutes in terms of the plain fact which semantic meaning provides, disjoined from any purpose that may give the statute coherent meaning and worth as human action. This separation of meaning and purpose, it is naively believed, guards against judges importing into statutes their subjective purposes under the guise of interpretation.

The better legal theory, I argue, is what may be termed moral legality. ${ }^{5}$ Like legal positivism, it agrees that judges ought not to "make" law as they prefer. Unlike legal positivism, however, and in agreement with rule skepticism, moral legalism does not believe that judges can find the law merely by its semantic interpretation. It instead argues that easy cases are no different in kind from hard cases, in which supposedly the law (as semantic meaning) runs out. It takes the position that all meaning in law is at bottom, like meaning elsewhere in human life, purposive meaning. Easy cases are easy simply because law's semantic meaning happens to match law's purposive meaning, and consequently no legitimate question of mismatch can arise. In fact, we may say, only if law's semantic and purposive meanings coincide as a rule can legal positivism have a predictable settling, and not an unsettling, moral force in society.

Moral legalism, however, is not without its problems. While it is sensible to think of a statute - and perhaps also a written constitution - as having purpose, because we can identify the time, place and people who intentionally enact them, on purpose, as it were, we cannot say the same of the common law or an unwritten constitution, much less of the law as a whole. Moreover, even to think of statutes having an intended purpose often

L.L. Fuller, The Morality of Law, rev. ed., (New Haven: Yale University Press, 1969) at 86 [hereinafter The Morality of Law].

5 Moral legality is to be distinguished from legal moralism. Legal moralists, whatever their controversial moral outlook, see the law as their coercive instrument to impose their moral values on everyone, themselves included. Paradoxically, legal positivists may consistently adopt legal moralism, instead of legal utilitarianism, if they choose to do it. In opposition, moral legality is the morality internal to the law. It inherently constrains the justification of law's positive use contrary to moral law in its Kantian conception. For this reason, moral legality does not exclude, but rather requires, the pragmatic thesis that all positive law necessarily is purposive and not passive action. But moral legality, unlike legal positivism or legal moralism, adds to pragmatic positive law the moral law constraint that it may not treat humans beings as means only, for that is contrary to their humanity or personality. A paradigm case of legal moralism is the Islamic statc. The paradigm theory of moral legality is Immanuel Kant's Doctrine of Right (or Justice). See I. Kant, The Metaphysics of Morals, trans. M.J. Gregor (Cambridge: University of Cambridge Press, 1991). 
encounters unresolvable difficulties. Statutes usually end up not having the intended purpose, but too many purposes, the wrong purpose or no purpose at all. Purposive theorists like Lon Fuller propose to solve this problem by finding purposive meaning not in the subjective purposes of legislators, individually or collectively, but in the statute's underlying purposiveness, what he refers to as "the intention of the design" the statute as a purposive whole displays, ${ }^{6}$ and which I interpret as the statute's purposiveness as if without purpose. Even semantic theorists like H.L.A. Hart concede that purpose can have important uses in statutory interpretation. ${ }^{7}$ The controversial point, as Fuller recognizes, is not that a statute or a particular law is a purposive thing, but whether law as a whole has purpose. ${ }^{8}$ Fuller sidesteps this controversy and argues only that his theory of the inner morality of law applies to the legislator who commands by enacting statutes. He does not address either constitutional law or common law, much less the law as whole, as having purpose in either sense. ${ }^{9}$

Ronald Dworkin has a bolder thesis. He argues against the legal positivism thesis that in hard cases judges have no choice but to make law as if judges were legislators. The same justification, or truth test, in answering questions of law when the law is settled is the same justification as when the law is unsettled. ${ }^{10}$ This is because law as a whole, as we continuously receive it, must be interpreted in its best moral light. (No one could truthfully argue that it be interpreted in its worst light.) What the best moral point of law

The Morality of Law, supra note 4 at 86.

As H.L.A. Hart now admits, judges cannot, as he once thought true, responsibly satisfy their fidelity to enacted law by restricting themselves to the question: "whether according to the settled conventions of language this [application of this statutory rule to this particular case] is determined or left open by the words of that rule." He recognizes that even if the case is undecidable because of linguistic indeterminacy, if the purpose of a rule is obvious or agreed, then judges may put purposive meaning to two important uses: to render determinate in application a rule whose application the conventions of language leave open, and to show that words in the context of this rule may have a meaning different from that which they have in the context of other rules, (Essays in Jurisprudence and Philosophy (Oxford: Clarendon Press, 1983) at 6-8, 106). The thesis I advance is that even when the purpose of a statute is not obvious or agreed it still has a right answer as an unfinishable legal fact.

The Morality of Law, supra note 4 at 145-46, 189-90.

I have insisted that law be viewed as a purposeful enterprise [of subjecting human conduct to the governance of rules], dependent for its success on the energy, insight, intelligence, and conscientiousness of those who conduct it, and fated, because of this dependency, to fall always somewhat short of a full attainment of its goals. In opposition to this view it is insisted that law must be treated as a manifested fact of social authority or power, to be studied for what it is and does, and not for what it is trying to do or become....[These legal positivists, however, would concede] that purpose has a proper role to play in the interpretation of individual legal enactments. A statute is obviously a purposive thing, serving some end or congeries of related ends. What is objected to is not the assignment of purposes to particular laws, but to law as a whole. (at 146)

I would agree with Fuller that legal positivism assumes that law is the finished fact, or no fact at all, of manifested social authority or power. Fuller, however, is not clear on whether he adopts a different conception of law as fact, or simply adds to it the prior condition of his theory of statutory law's eight maxims of inner morality.

L.L. Fuller, The Principles of Social Order, ed. by K.I. Winston (Durham: Duke University Press, $1981)$ at $39-40$.

S. Guest, Ronald Dworkin (Edinburgh: University of Edinburgh Press, 1992) at 6. 
is, of course, is controversial, but it is a controversy that by its nature is always answerable by the stronger argument as the right answer. Unless law as a whole is given this moral unity, not even easy cases are answerable, rightly or wrongly. They are merely cases that successfully hide behind semantic law, and thus appear beyond controversy, even when semantic law fails the integrity of law's best moral point. Once it is understood that all received law must have the unity of moral purpose, then easy cases and hard cases take on a difference of continuity of difficulty and not of unbridgeable discontinuity. Dworkin's "right answer" thesis is, however, expectedly contested as a general theory of law. It cuts too much against the grain of legal positivism. Nonetheless, I argue, it is still the best thesis to account for enabling statutes, like the Universities Act.

Moral legality, as I propose it, adopts Dworkin's theory of justification: the right answer in law is a matter of interpretive integrity. This integrity is found not in legal positivism's plain fact of law as it is, nor in natural law's metaphysical law behind law, but instead in what Dworkin calls "law beyond law"." This law beyond law is the law beyond the "inclusive integrity" judges can give it from case to case. It is the "pure integrity" only the community can give law as it works itself pure over time. But moral legality cannot go so far as to accept Dworkin's concept of purpose that is to serve as law's moral point. It cannot accept as the concept the intended purpose the community personified can be persuaded to adopt as its self-justifying end in view, that in turn sufficiently justifies all actions to realize it, in the same sense that people as persons individually or collectively justify the harm their actions do to others. This personified concept of purpose better fits legal moralism and its purposive righteousness than moral legalism and its concept of purposiveness without righteous purpose.

Moral legalism, moreover, could not accept Dworkin's concept of purpose even if it found its content politically attractive or even objectively warranted in terms of his truth test of constructive reflective equilibrium. ${ }^{12}$ Dworkin controversially finds law's moral purpose or communal end in view in his postulated duty of the equal respect and concern political government owes its citizens, not equally, however, as most would assume, but "as equals." ${ }^{13}$ From this postulation, he argues that government can satisfy its duty to treat its citizens as equals by providing equality of opportunity, equality of rewards or equality of resources. He argues that resource equality, in competition with rival conceptions of equality, makes the best coherent moral sense of the law as a whole. He argues this, however, as a matter of political morality - which, I suggest, is a version of legal moralism - and not as a matter of moral legality.

Moral legality, if it is successfully to oppose legal moralism, must exclude all communal versions of the good as the collective end in view. This includes conceptions of distributive justice of Dworkin's political morality as well as of traditional world religious moralities and modern ideologies. Dworkin, I think, would agree that the opposing outlook, legal moralism, whose form demands in practice as law's necessary 
maximal content the majority's morality, should be rejected. It would be inconsistent with the liberalism he avows that makes it unconditionally wrong for the law coercively to favour any comprehensive conception of the good life as the universal norm. ${ }^{14}$ It is not clear, however, that he could fully accept moral legality, which demands as law's necessary minimal content political government's first duty to treat all persons as moral equals, and only thereafter as empirical equals according to some particularistic (local or global) conception of distributive justice. Moral legality, in other words, demands that all people be treated equally as moral persons before they can, as citizens with differing resource demands, be treated as empirical equals. But this controversy for present purposes need not be resolved, since what moral legality finds useful is Dworkin's idea of interpretive integrity both as inclusive integrity and as pure integrity beyond it, and not his version of pure integrity as "utopian legal politics". ${ }^{15}$

Inclusive integrity for Dworkin sufficiently refutes the skeptical view that hard cases can have no right answer. It provides the continuity between easy cases and hard cases by bringing both into line with the best moral point that received law permits within the institutional constraints it places on social justice, specifically the constraints of democratic fairness that commands judges not to remake the statutes they apply and procedural due process fairness that commands judges to follow their past decisions to avoid unfairly unsettling reliance on expected rights and duties. Pure integrity goes beyond inclusive integrity by abstracting from it everything but social justice to those whose unequal resources bar them from accessing equal opportunities. But not even Dworkin's ideal judge, Hercules, can move directly or all at once toward the image he has of law's dream without violating law's overall integrity of process, fairness and justice. But he can by working indirectly from hard case to hard case exemplify the self-fulfilling attitude that law does work itself pure, and thereby show that optimism and not pessimism satisfies Dworkin's conception of truth as "articulate consistency", the duty to submerge private convictions in accordance with public principle. ${ }^{16}$

Moral legality argues against legal moralism that only it can make possible, without deception the attitude of law working itself pure, and so agrees with Dworkin's claim that interpretive integrity justifies rational hope. But moral legality, as I propose it, does not exclude from law's best overall moral point either democratic fairness or legal fairness, to leave only resource fairness. It instead argues that all three concepts must have their correct priority, and takes as the supreme standard the universal morality that best dovetails with legality as the basic constitutional norm. While moral legality does not dictate what conception of distributive justice basic constitutional norms ought to have, it constrains that choice. This constraint of moral legality is usefully expressed in the preamble and s. 1 of the Canadian Charter of Rights and Freedoms as the rule of law in a free and democratic society under God. Without this theory of constraint, I suggest, the integrity of the constitutional dimension of moral legality would be jeopardized, and with it received law itself.

R. Dworkin, "Liberalism" in S. Hampshire, ed., Public and Private Morality (Cambridge: Cambridge University Press) at 113.

15

16 
Moral legality, as I suggest it, holds, among other things, that judges not creatively interpret statutes even in hard cases, that is, that they not make the existing law conform independently of constitutional morality to some freely constructed vision of distributive justice, not even if the "philosophic community" deems it, after a free encounter, the best argument. But moral legality also holds that in hard cases judges must interpret; they cannot simply find the right decision by comparing the facts of a case with the existing law to see if they match or correspond exactly, or by analogy or example disconnected from purpose. In other words, on the one hand, moral legality holds that inclusive integrity constrains the judicial pursuit of pure integrity to exclude its creative kind of interpretation, even in hard cases. That kind of interpretation may be appropriate at the level of constitution-making by the people in general, the kind that aims to bring a visionary future of a specific theory of distributive justice as a new plain fact into the present. On the other hand, it holds that the plain facts of existing law are never finished facts in the sense legal positivists and legal moralists alike think, not even when they are semantically established in constitutional law - and, I think, as well, as Dworkin thinks possible with his constructivist theory of philosophic argument. ${ }^{17}$ Plain facts of existing law are unfinishable legal facts, even the fact that makes the basic constitutional norm the rule of law and not the rule of despotism. The clearest instance of such unfinishable legal facts, I suggest, are enabling statutes, like the Universities Act.

In telling the story of the purposiveness of the Universities Act, I thus tell it from the general outlook of moral legality, the outlook that sees statutory purposiveness, as if without purpose, as not only an unfinished but an unfinishable plain fact of the law. I first tell its story of inclusive integrity to show that because cases randomly arise before courts it is the best kind of story judges can tell over a series of cases to overcome fragmentary interpretations. In this story, judges look for purposiveness as manifested by the so-called intention of the statute's design or scheme, and they either relegate purpose as the subjective intention of legislators to evidence of the statutory scheme, or reject it.

I next tell it as a story of pure integrity to show that because inclusive integrity may misfire, it is the best kind of story judges can tell to overcome misdirected interpretations, those that fail to best fit a statute's scheme within the pure integrity of constitutional purposiveness. ${ }^{18}$ In this story, judges ideally constrain the legislature's visionary purpose of any statute in light of the underlying purposiveness of the law itself as best, but not infallibly, expressed in a constitution, in the present case, in the Constitution Act, 1867 and in particular the Canadian Charter of Rights and Freedoms. This means that they look not simply to find "out there" plain legal facts, nor to construct new ones, but rather continuously in light of new experience to reconstruct systematically in a series of cases the unfinishable legal facts they find.

I cannot in an essay do justice to telling the story of the purposiveness of the Universities Act as an unfinishable legal fact. But I can indicate what the story would look like if it were fully told, and to suggest why it would be futile to try to add to purposive

18 For the classic study of a statute misfiring by misdirected judicial interpretation, see E.H. Levi, Introduction to Legal Reasoning (Chicago: The University of Chicago Press, 1949) at $62 \mathrm{ff}$. 
stories of statutes or of the law itself the final chapter to end further chapters, even though to try to do it, as Dworkin argues, is law's proper ambition. And, as an aside, telling this story might suggest how legal theory must figure centrally in whatever judges do.

\section{TELLING THE STORY OF INCLUSIVE INTEGRITY}

The 1966 Universities Act traces its history back to the first session of the first Legislative Assembly of Alberta, and its establishment, by the 1906 University Act, ${ }^{19}$ of a "body politic and corporate" it named the University of Alberta. The Senate composed of the Minister of Education, ten members appointed by the Lieutenant Governor-in-Council and five members elected by the convocation, which was composed solely of University graduates - had the power, by s. 27 :

[to manage and superintend] all affairs, concerns and property of the university and in all cases unprovided for by this Act it shall be lawful for the senate to act in such manner as shall appear to it best calculated to promote the purposes intended to be promoted by the university....20

The 1966 Act did not set forth these intended purposes in so many words. Even if it did, since purposes are never definitely specified by words, but only by deeds, the purposive clause would permit the Senate the wide discretion to define by its acts what a university is. It could not, of course, act outside its statutory powers, but these powers were unrestricted, even as to the teaching staff, as the following Senate power indicates:

to prescribe examinations and confer degrees and to appoint at such salaries as it shall think fit and at pleasure to dismiss all professors, tutors, lecturers, teachers and other necessary officers, assistants and servants of the university. ${ }^{21}$

In addition, by s. 41 , the Senate had the power to determine the faculties or disciplines of learning the University was to have.

This unchecked power over academic work assigned the Senate, however, was not really its power. Since the provincial government had the majority of appointments, in substance the power of the Senate was the power of the provincial government. In any event, the Senate, as inclusive integrity would permit, could choose to define the University as if it were an extension of a public high school. Whether that would be the result depended, of course, on what purpose the Senate would adopt, not by words but by deeds, as directing its course of action in appointing teaching staff and defining their duties and criteria for promotion and dismissal. This purpose could be the subjective intentions of a majority of Senate members, perhaps influenced by the provincial government, in which case just about anything could legally happen. Or it could be a [hereinafter 1906 Universities Act]. It would appear that under this $A c t$ the University could be located in either Calgary or Edmonton. 
more general purpose that would be faithful to the idea of a university as received tradition would have it.

In 1910 , this statutory uncertainty of purpose became legally moot. In that year, the 1906 Act was repealed and re-enacted, and the structure of power within the University radically altered. ${ }^{22}$ The full corporate status of the Senate, its absolute power over all employees was not conferred on the newly-created Board of Governors as the corporate body. This change, as held in Powlett, ${ }^{23}$ in 1934, was pivotal in more than one way. It had the immediate effect of reducing the University to "merely...an institution of learning. ${ }^{124}$ It was no longer the legal entity that in law could sue or be sued. ${ }^{25}$ It was no longer an integral part of the corporate body called the Senate. It now had a different existence in law independently of the Board of Governors. To be sure, the Board still retained the power to appoint and define the tenure and duties of the teaching staff of the University, as well as to promote and dismiss them, but only in the residual sense, as the words of s. 28(b) show:

28.(b) To appoint Deans of all the faculties, the Librarian, the Bursar, the Registrar, the professors, teachers and instructors of and in the University, or any of such officers as the Board may deem necessary for the proper conduct of the business of the University, together with all such other officers, clerks, employees and servants as the Board shall deem necessary, and, subject as hereinafter mentioned, to fix the salaries or remuneration of such officers, and to define their duties and the tenure of office or employment, which, unless otherwise provided, shall be during the pleasure of the Board.

Provided that no person shall be appointed as a Dean of any faculty, or as a member of the teaching staff of the University, or of any faculty thereof, unless he has first been nominated for the position to which it is proposed to appoint him by the President of the University.../nor] promoted or removed from office except upon the recommendation of the President of the University. ${ }^{26}$

This language by its plain meaning and scheme no longer leaves the ultimate governing power, now the Board, the extraordinary corporate power to characterize the defining purpose of the University. The purposive clause is omitted, and the effective power over the merits of the appointment of teaching staff is placed in the office of the President, as the chief academic officer. That office must nominate or recommend deans and faculty members before the Board may appoint, promote or dismiss them. Thus, it would be the purpose intended by the President in making recommendations that would give the University its real character as an institution of higher education. This denial of unchecked power to the Board did not mean, however, that it entirely lost ultimate authority over the teaching staff. For reasons of sound financial management at least, it would have not only

An Act Respecting the University of Alberta, S.A. 1910, c. 7 [hereinafter 1910 Act].

Powlett and Powlett v. University of Alberta, [1934] 2 W.W.R. 209 (Alta. A.D.) [hereinafter Powlett]. Only the Board of Governors and not the University or the Senate is suable for negligent harm caused students by instructors or other students.

Ibid. at 216.

Ibid. at 246.

[Emphasis added]. "Teaching staff" was defined "as including professors, associate professors, lecturers, instructors, demonstrators, and all others engaged in the work of teaching or giving instruction." 
the power but the responsibility to refuse the President's recommendations to appoint. And it always has had the power to appoint and dismiss the President.

It was specifically on the basis of this altered statutory scheme that Powlett held that under the $1910 \mathrm{Act}$, Board appointees to the teaching staff of its University are not "scholarly servants" carrying out orders of the corporate body, but rather they are appointed as officers to carry out the public interest in university teaching. Adopting the words of an American judge, Cardozo J., the Court said:

The governing body of a university makes no attempt to control its professors and instructors as if they were its servants. By practice and tradition, the members of the faculty are masters, and not servants, in the conduct of the class room. They have the independence appropriate to a company of scholars. ${ }^{27}$

If this, then, is the underlying purposiveness of a university, namely to acquire and impart further learning by a company of scholars learned in their disciplines and engaged to teach it professionally, then reducing the Board's plenary power to select whom to appoint to teach by the condition precedent of the President's recommendation, we may infer, is to further that purposiveness and not the subjective purposes a President may have in mind contrary to it.

The 1966 Universities Act has continued the 1910 provision that made the President's recommendation a condition precedent to the Board's ultimate authority over appointment, promotion and dismissal of academic staff. But the 1966 Act also significantly moved further in the direction of providing the institutional arrangement to facilitate "the independence appropriate to a company of scholars." This further movement in fact was called for by the Report of the Governors of the University of Alberta. ${ }^{28}$ This 1965 Report was the report that recommended academic autonomy the year before the legal establishment of the University of Calgary in 1966. Among its six fundamental recommendations, aside from the first one that the University of Calgary become a separate provincial University, two are of special interest.

\section{Recommendation 4 continued a Board of Governors:}

As a body corporate having the ultimate authority in all the affairs of its University. While its main role would be fiscal and proprietary, the Board should be more than a mere trustee - it should also be concerned to see that the academic functions of its University are being carried out.

We consider that in discharging its functions the Board should have well-defined methods of communicating and consulting with its General Faculty Council, and that the two bodies should act in the conjoint or cooperative exercise of their powers wherever indicated. ${ }^{29}$ 
This recommendation indicates that the Board is to have the independent power of a trustee over the fiscal and proprietary business of a university, and not merely the power of an agent accountable to the Provincial government. The recommendation also has General Faculties Council continuing as the senior academic body of the University (with appropriate independent powers) and that, where indicated, the two bodies are to act conjointly and cooperatively. It further states that the Board is not to limit its responsibility to its trust duties, and to shut its eyes, as it were, as to whether its University, specifically, the Council and the President, are discharging their academic duties.

Recommendation 5 also continues the statutory arrangement of a General Faculties Council as the senior academic body of the University. It explicitly states that Council would have as its main responsibility not only the maintenance of academic standards, but also the immediate power to guide its University's academic growth. The recommendation then continued:

Recognizing the inevitable intermingling of academic with many fiscal or proprietary matters, the General

Faculty Council, under the authority of the Board, should have the power of decision in some areas and powers of initiation or of recommendation in others. ${ }^{30}$

We may fairly infer, I suggest, that this language suggests what Recommendation 4 means when it says the two bodies should act conjointly or cooperatively wherever indicated. When Council's powers are to initiate or to recommend, the inference is that the Board may directly and specifically refuse the initiations or recommendations. When Council's power is a power of decision, however, the indication would be that the Board's ultimate authority is not the power specifically to override. The statutory power of decision assigned Council would lose its point if it were construed to permit the Board to reject it as if Council's power of decision were a mere power to recommend. The plain meaning of "decision" denotes a final choice, whereas "recommendation" is merely advice.

We find the underlying purposiveness of Recommendation 5 making its way into the following section of the 1966 Act:

19. (1) A board may,

(a) subject to subsection (3), appoint such officers and employees as it considers necessary for the proper conduct of the affairs of the university and promote and dismiss any such officer or employee....

(3) A person shall not be appointed to, promoted to or dismissed from 
(a) any position on the academic staff of a university....except upon the recommendation of the president made in accordance with procedures approved by the general faculty council. ${ }^{31}$

In prior Acts, only the recommendation of the President to appoint, promote and dismiss faculty members was a condition precedent to the Board's general power over these matters. This new arrangement would appear further to foster the purpose of a university and the independence appropriate to a company of scholars. A Board would have the special expertise to supervise in detail the president and other officers and employees engaged in the fiscal and proprietary business affairs of a university. But since it would not have special expertise in academic matters, its ultimate supervisory power to review academic performance would be exercised indirectly through its exclusive powers over financial matters.

The statutory arrangement the $1966 \mathrm{Act}$ innovates takes this rationale one step further. Not even the most academically qualified scholar in the presidential office could personally have academic expertise in all disciplines of learning. Thus the point of the President's recommendation is not simply to check and balance the Board's ultimate power to appoint, promote and dismiss academic staff. It is also to represent, as well as supervise, academic judgment on these matters in the relevant discipline. Such representation depends on procedures appropriate to the task. In the absence of a statutory provision, the President would have the power to prescribe such procedures. But the 1966 Act confers the power to approve these procedures on the General Faculties Council, the body that collectively represents, as the senior governing academic body, the various faculties or disciplines of learning that constitute a university.

This innovation, independent of its semantic expression, comes to the same result when interpreted purposively. If there is to be a set of procedures the President is to follow in recommending to the Board academic appointments, promotions and dismissals, only three arrangements appear possible. First, the Act could have specified that the President is to follow procedures approved by the Board, but its words plainly do not do that. Had the Act done so, it would have, contrary to Powlett, permitted the Board to put itself directly in academic control of the company of scholars, to subject itself to liability for their academic mistakes, to nullify the point of the prior presidential recommendation, to contradict tradition and practice, and to render incoherent the idea of a university as a company of scholars. ${ }^{32}$

Second, the 1966 Universities Act could have continued the silence on the matter. Since the $1910 \mathrm{Act}$, the President had the power to recommend academic appointments, promotions and dismissals. The 1966 Act could have continued to leave it by default to the President to choose arbitrarily: to choose in effect not to legislate any procedures at all, or to legislate procedures that would permit recommendations contrary to "the independence appropriate to a company of scholars." 
But, third, the plain meaning of the 1966 Act did neither. Its inclusive integrity would exclude both these alternatives, as the words in ss. 19(1) and (3) make clear. The President is no longer to have by default the approval power over the initial procedures to appoint, promote and dismiss academic staff. The Act in s. 19 expressly assigns this power to the Council and does so without making it expressly subject to the Board's overriding authority, as it does in s. 34 with respect to Council's general powers over academic affairs. The Act does so, we may purposively infer, because the Council, as Recommendation 5 stated, is to have "the main responsibility and immediate power in guiding its University's academic growth and in maintaining academic standards."

This inclusive integrity of the 1966 Act appears confirmed by the purposiveness first set by the 1910 Act. Under it and subsequent Acts, the University remains the company of scholars engaged in academic work, as distinguished from the business affairs the President and the Board conduct separately and in support of the academic work. The Acts, beginning with the first one in 1906, divide the company of scholars into faculties or disciplines of learning, as is appropriate for a university. The 1966 Act overcomes this fragmentation in self-governance by establishing a General Faculties Council, whose membership is to consist of a majority of full-time academic staff proportionately representing their faculties. It thereby makes it possible for the company of scholars to govern themselves. Since it is this body that is most knowledgeable of academic standards, it makes good sense to empower it to fix the criteria within the procedures to appoint, promote and dismiss academic staff, and to guide future university growth.

As Recommendation 4 stated, however, General Faculties Council is not to have the unfettered right to exercise its general powers over academic affairs to initiate, recommend and decide. These are the powers listed in s. 34 of the 1966 Act..$^{33}$ As already discussed, they are expressly subjected to the authority of the Board. Council's power in s. 19(3), the power to approve procedures for appointing, promoting and dismissing academic staff, as a condition precedent to the powers of the President and the Board, would be subject to the Board's residual power to check and balance it.

The Board's power to review and check Council's approvals of these procedures or decisions on academic growth or any other academic matter can be decisive without interfering with academic judgment. The Board has the complete authority, as the University's corporate body over business affairs, specifically to make contracts of employment, and correlatively to incur the legal liability to perform them. This power and liability is not to be diminished by the powers of the General Faculties Council or the President over academic appointments. The Board may refuse - but, of course, only in good faith as the public trustee of the University's finances and property - to contract for academic services, just as it may refuse to contract for administrative and other business services. Neither the Council nor the President, nor both together, can compel the Board - in the absence of bad faith in carrying out its statutory duties - to contract to fill the academic positions the President recommends in accordance with the procedures Council approves. 
The possible incompatibility of purpose between the Board's proprietary trusteeship, on the one hand, and the Council's academic trusteeship, on the other hand, is avoided by the Act's scheme to separate the University's corporate governing structure over business employees from the distinct academic governing structure of its company of scholars. The incompatibility would arise only if the Board were to treat academic appointees as if they were business employees, and tried, for example, to initiate their appointments in disregard of the two conditions precedent, the Presidential recommendation and Council's appointment procedures.

Inclusive integrity would have courts nullify such action on the ground that the Act's scheme prohibits it. There would be no need to resort to pure integrity, the full purposiveness of the scheme, as it were. The purposiveness implicit in the scheme is plainly to deny the Board the power to initiate not only appointments, but also promotions and dismissals, as to teaching staff or other appointees with the duty of academic work. The purpose behind this purposiveness, again, is to facilitate and respect "the independence appropriate to a company of scholars."

Not all the words which the 1966 Act makes semantic law, however, are as well attuned to its underlying purposiveness or scheme we have so far discerned. The words which express the scheme of conditions precedent on the Board's power to appoint, promote and dismiss academic staff come expectedly from the 1966 Act, s. 19, that has to do with the general power of the Board over both business and academic affairs. On the other hand, the general power of Council, the power to deal only with academic affairs, is found in s. 34. Certain words in this section, however, appear to present a different scheme, one that possibly undercuts the scheme of conditions precedent in $\mathbf{s}$. 19(3), thus raising an issue initially of inclusive integrity, and subsequently of pure integrity.

The argument that the apparent scheme of s. 34 contradicts and overrides the s. 19 scheme may be constructed semantically. Section 34 assigns General Faculties Council the general power over the academic affairs of the University, and then sets forth an incomplete list of specific powers. All these powers are subject to the authority of the Board. Among them is Council's power in s. 34(1):

(o) to make recommendations to the board with respect to...procedures in respect of appointments, promotions, salaries, tenure and dismissals, and any other matters considered by the council to be of interest to the university. ${ }^{34}$

All these powers of Council referred to in s. 34, unlisted as well as listed, are, by the express introductory words of the section, subject to the authority of the Board. Council's power in s. 19(3) to approve procedures concerning appointment, promotion and dismissal of academic staff is one of the unlisted powers of s. 34, and thus it is subject to the Board's authority to reject directly and specifically as if it were a mere recommendation. We may call this the duck side of the story, as in the figure-background relation. 
The opposing argument, the rabbit side of the same story, may also be constructed semantically. Section 34 may subject Council's unlisted as well as listed powers to the authority of the Board. The question, however, is the manner in which they are subjected. By s. 34(1)(o), Council has the power to recommend, not approve, matters dealing, inter alia, with academic appointments, promotions, and dismissals. It is only Council's recommendations that are, by the express words of s. 34(2), to be transmitted to the Board through the President. They are to be transferred by statutory direction so that the Board may treat them as recommendations, and either accept or reject them.

But Council has listed in s. 34(1) powers of initiation and decision as well as recommendatory powers. It has at least the unlisted power of approval in s. 19(3):

19(3) A person shall not be appointed to, promoted to or dismissed from

(a) any position on the academic staff of a university...

except upon recommendation of the president made in accordance with procedures approved by general faculties council. ${ }^{35}$

By the plain meaning rule, Council's s. 34(1) powers of initiation, decision and approval are not recommendations. The Board cannot treat them as recommendations. It would appropriately treat Council's powers of initiation as subject to its authority to continue them or not, and its powers of decision and approval as subject to its authority to check and balance through financial constraints. It would thus appropriately receive these matters for information only. The Board, in other words, it would appear as a matter of the 1966 Act's purposiveness, would have no power specifically to reject what Council approves as the procedures that condition the validity of the President's power in s. 19(3) to recommend to the Board academic appointments, promotions and dismissals.

It could be that further argument over the plain meaning of these provisions and their apparent conflict may show a different result, or instead that semantic law has simply run out. Moreover, what has so far been discussed should suffice to show that the words in s. 19(3) and s. 34(1)(o), when juxtaposed, are not perfectly plain as a finished legal fact, as if they cannot help but to reveal their meaning without ambiguity. For any of these reasons then, we should turn to the purposive story of inclusive integrity. It would put different questions. Which reading best fits the statute's purposiveness or scheme as a whole? Which reading makes all parts of the statute most workable? Which reading best preserves the opposed reading?

The duck reading, to win, would have to argue that the rabbit reading is totally cancelled. Council's power to approve in s. 19(3), while it binds the President, is really no more than a recommendatory power the Board may independently reject, and thus free the President to recommend without the condition precedent. The duck side would in effect have to argue that the Act be read as if its words were the following: 
19(3) A person shall not be appointed to, promoted to, or dismissed (a) from any position on the academic staff of a university...except upon the recommendation of the president made in accordance with procedures approved by the general faculty council, but only if the board also approves them. ${ }^{36}$

The rabbit side, to win, does not have to abolish the duck side. It does not have to argue that the Board is altogether helpless to check what Council approves as academic procedures under s. 19(3). It would in effect only have to argue that the Act be read as if its words were the following:

34(1) Subject to the authority of the board, but only insofar as this Act does not elsewhere limit its authority... ${ }^{37}$

The language the rabbit side would add, far from cancelling the duck reading of the $\mathbf{s}$. 34 scheme, not only leaves it intact, except insofar as other sections expressly modify it, but also, I suggest, makes the best sense of the 1966 Act as a purposive whole, that is, in terms of facilitating the self-government of a company of scholars.

For one thing, interpreting the rabbit scheme as prior to, but not contradictory of, the duck scheme leaves it workable in the right manner. The Board still retains its review power over academic appointments, promotions and dismissals. To exercise it, it does not matter who has approved the academic procedures, whether it is Council, the President or some other body. Since the Board is more than a managing trustee of the University's property, but it is also charged with the general review of academic affairs, if the procedures underlying the President's recommendations for appointments, promotions or dismissals are inappropriate to maintaining the academic standards of the company of scholars, it would not matter that Council had approved them. The Board would be obligated to act on its judgment and refuse the President's recommendations.

For another thing, as a matter of inclusive integrity, the rabbit scheme makes better sense of the duck scheme than it makes of itself. The powers of Council, the President and the Board generally are to work together in the check and balance scheme the 1965 Report recommended. The fact that Council's power in s. 19(3) to approve academic procedures is not a power of recommendation does not prohibit the President from transmitting such procedures to the Board, not as a recommendation the Board could reject, but as necessary information for the Board to have for purposes of its power to "see that the academic functions of its University are being carried out." ${ }^{138}$ Thus, it may even be said that the language the rabbit scheme would add to the Act, as a purposive whole necessarily implies.

What the story of inclusive integrity so far shows in general, I suggest, is the way in which purposive principles, such as the principle of necessary implication from the statutory scheme, flow from its very idea. Words the legislature did not expressly write into the statute, it nonetheless "intended" by virtue of the purposiveness necessarily 
underlying the statutory scheme it approved, independently of whatever subjective purposes it may have had in its collective mind, or in the individual minds of the legislators voting for it.

Another example of how inclusive integrity generates mediating principles in the interpretation of statutes by their scheme or purposiveness, and of the 1966 Act in particular, is National Union. ${ }^{39}$ It tells about the clash between two principles of inclusive integrity and how it reconciles them: the principle of generalia specialibus non derogant (general words do not derogate from special words), and the principle that a later statute overrides or silently repeals contradictory provisions in an earlier one. The Board of Governors of the University of Alberta, under the special words of the 1910 Act, had no duty to enter into collective bargaining, but had that duty under general words in labour legislation, first enacted in 1926. In the spirit of inclusive integrity, the Court held that: "where there are general words in a later Act which are capable of reasonable and sensible application without extending them to subjects specially dealt with by earlier legislation.... [then judges] are not to hold that earlier and special legislation indirectly repealed, altered or derogated from merely by force of such general words, without any indication of a particular intention to do so." In the absence of such indication, "the [later] general statute is read as silently excluding from its operation the cases which have been provided for by the [earlier] special one. 140

This application of inclusive integrity in National Union - that general words must not derogate from special words - I suggest, applies to resolve in favour of the rabbit scheme the semantic conflict between the words in s. 19(3) and s. 34(1)(o). The words in s. 19(3) are special words. They specifically state two conditions precedent that reduce the general power over employment the s. 19(1) assigns the Board. The Board cannot initiate employment, promotion or dismissal of academic staff, as it can with other university staff. It must wait for a recommendation from the President made in accordance with procedures approved by Council. The words in s. 34(1)(o) are general words. They permit Council to make recommendations to the Board through the President on many things besides academic appointments, promotions and dismissals. Consequently, these general words are to be read as silently excluding from their operation the words in $\mathbf{s .}$ 19(3). To do otherwise, it would seem, would defeat the manifested purposiveness of the 1966 Act's scheme.

Inclusive integrity, of course, in theory, never stops until all possible issues are exhausted - and potentially there are always possible issues. The 1966 Universities Act, like all enabling statutes serving an important public interest, is an unfinishable legal fact. So far we have only been able to tell a part of its story, no more than a first chapter at most. Other chapters could be added, ${ }^{41}$ and they would usefully enlarge the Powlett story University of Alberta (1993), 42 W.W.R. 560 (Alta. Q.B.) [hereinafter National Union].

41 For one thing, we could discuss cases in which the plaintiff, who has a temporary academic appointment, has been denied tenure, which usually means termination from any academic position. We could point out that courts refuse, for reasons of inclusive integrity, to intervene into the 
as to what is most important in the idea of a university. While a university is a place of people and buildings that is a public business managed by a corporate body in trust for the future public, more importantly it is also a distinctive enterprise in which a company of scholars have the independence appropriate to their academic calling, the independence we usually refer to as academic freedom, and more accurately as responsible selfgovernment. But to talk of academic freedom and collegial self-government is to talk beyond the inclusive integrity of Powlett to the pure integrity of statutes like the $1966 \mathrm{Act}$. But that is another kind of story, the one to which we now turn.

\section{TELLING THE STORY OF PURE INTEGRITY}

The story of the 1966 Universities Act, the statute Calgarians needed so as to have the University they sought, is, as we expect, by no means completed as a story of inclusive integrity. This, as we have seen, is the story of judges trying to unify, for settling the litigation of rights, opposed stories about the Act's purposiveness and the meaning of its rules. Much more could be told, and the telling would never stop as long as controversies over the Act may arise that only courts as a last resort can settle. But to continue the Act's story of inclusive integrity would miss the more important point, to see what the final chapter would at least look like.

For this reason, we need to tell the story of pure integrity in its own right, as the story of what the 1966 Universities Act is itself trying to do, the story of its underlying purposiveness that may even surprise the legislators who voted for it. This is the story, I suggest, that ideally people in Alberta - and elsewhere in similar circumstances would be telling each other and their government not only in 1966, but continuously. It is a story, however, that cannot be told in a void, without first having told the story of inclusive integrity, in our imaginative reason if courts have not yet adequately told it. Fortunately, Powlett provides us with much of the first chapter from which we may project to the best bet of what the final chapter would look like.

This first chapter, if it were told at once as a whole in sequence, would begin at the beginning with the first University Act in 1906 and its radical revision in 1910. It would tell us that in the $1910 \mathrm{Act}$, the power to initiate academic decisions was removed from the Senate and assigned to the President. This left in the newly created Board of Governors effectively only the power to reject the President's recommendations on appointing, promoting and dismissing members of the University's company of scholars. The Board, as Powlett held, was not itself in corporate control of both the business affairs

academic merits of denying tenure. They instead defer to the judgment of the company of scholars and confine themselves merely to review the fairness with which Council's procedures were employed. We could also see that this deferential approach can reflect pure integrity, the idea that courts should facilitate, insofar as inclusive integrity permits, the independence appropriate to a company of scholars. See e.g. Red Deer College v. Michaels and Finn, [1975] 5 W.W.R. 575 (S.C.C.). For another thing, we could discuss the incipient threat to the pure integrity of a university's purpose, the critical collegiality within the university that makes academic freedom possible, that comes from legislation that requires the company of scholars to convert themselves into a labour union with the right to strike. See e.g. P. MacKinnon, "Labour Relations in the Academy: A Case Study at the University of Saskatchewan" (1991) 14 Dalhousie L.J. 355. 
and the academic affairs of the University as the Senate had been under the 1906 Act. The University was no longer part of the single corporate person it was until 1910 when Powlett in 1934 ironically characterized it as "merely... an institution of learning."

Had the Powlett Court directly considered the question of pure integrity - which, I argue, inclusive integrity always necessitates courts to consider at least implicitly - it would publicly have inquired much further into why the purposiveness underlying the 1910 scheme necessitated radical reduction of the total corporate power the Board had under the 1906 Act's scheme. But, although judges must always think of statutes as having purposiveness, they are wise not to go further in their elaboration of it than the disposition of the instant case requires. In Powlett, to determine the liability in negligence of the University of Alberta toward its students, the Court had to consider the underlying purposiveness of the 1910 Act's scheme. The disposition of the case required it to determine whether academic staff were "scholarly servants" of the Board, and to that extent to enter into the law beyond the law of the 1910 Act.

The Court held that because the University of Alberta, under the 1910 Act, consisted of a company of scholars, independently of the Board as the corporate and suable body, it was not a legal entity that could be sued. The University was an independent entity wholly created as a legal fact by statute, existing solely as a part of its scheme. That scheme meant that scholars as a distinctive company or enterprise had to have the independence appropriate to their calling. They could not teach by taking orders from the Board; they could teach only by giving orders to themselves. A company of scholars, in other words, could not be "scholarly servants". If the Powlett Court had to go further in developing grounds for its decision, it would have had to consider the pure integrity of the 1910 Act and the fact that the idea of a company of scholars purposively connects with the related ideas of academic freedom and collegial self-government.

In telling the story of pure integrity, we can free ourselves from the institutional constraints that compel courts to stay within inclusive integrity, but we are not free of inclusive integrity itself. We must always test that the two stories dovetail, otherwise pure integrity misfires, unless inclusive integrity is found at fault. We start with the theme within inclusive integrity that promises the best interpretation of the series of statutes the Legislative Assembly of Alberta has enacted. The more promising theme, I would conjecture, is the Powlett theme that the term "scholarly servants" is an oxymoron, and that a company of scholars who by purposive necessity have independence appropriate to their calling best expresses the underlying purposiveness of the 1910 Act, even if no one who voted for the Act before the Court pronounced it had thought of it. The independence appropriate to a company of scholars is the independence that best fits not simply the purposiveness of a provincial statute establishing a university, but that in turn best fits the purposiveness of the Constitution of Canada as it evolves over time.

This means we start the story of pure integrity with s. 93 of the Constitution Act, 1867, which distributes the exclusive power over education to the provinces. Statutes, whatever 
the name given them, fall within the provincial education power if their scheme exhibits education as its primary purpose - what the courts call the statute's pith and substance, which could be a finished legal fact. ${ }^{43}$ The several Alberta Acts since 1906 establishing universities of course qualify as having education as their primary purpose, the purpose that best characterizes the purposiveness of their schemes.

Curiously, we confidently know this, even though the Acts do not literally describe their purpose as higher education. We know it for two reasons. Not only is it plain fact that "university" means education, but it is also plain fact that the schemes of teaching, instruction and academic work the Acts set forth connect with education. Moreover, the plain meaning of "university" in dictionaries unambiguously defines it as an institution of higher learning with teaching and research facilities, comprising a graduate school, professional schools and an undergraduate division. This plain meaning corresponds to the scheme the Acts have consistently set forth.

Surprisingly, the words of the series of Acts say nothing about research or academic freedom. But again we confidently rely on the underlying purposiveness of what is meant by the legal fact that the Acts establish universities. Powlett, we may recall, because it was constrained by inclusive integrity, did not discuss either the research obligation or the academic freedom of the company of scholars, and only implied the purposive necessity of their collegial self-government. Interpreting the Acts to bring out their best point as pure integrity, however, immediately brings these features to light. It could hardly be otherwise. "Scholarly servants" taking orders in teaching and researching simply does not fit the underlying purposiveness of a university, despite what legislators may intend.

In fact, all that we are told by the plain meaning of "university" as if it were a finished semantic fact of law is that it is an institution of higher education or learning. This definition obscures the fact that lines still have to be drawn. A university is something more than a college, which grants only undergraduate degrees and thus does no research, and more than a research institute, which grants no degrees and may do only mission research. The something more, in the sense of giving it is best purposive interpretation, is that a university, originally a place only for professional schools serving the state interest, combines the functions of teaching and research with philosophy, philosophy in its best sense as the foundational discipline whose purpose since Socrates is critical inquiry into the truth of things that is settled by the stronger argument. ${ }^{44}$

Characterizing a statute as a plain finished fact of legislative purpose by using its name, when the scheme matches it, is illustrated by $R$. v. Crown Zellerbach, [1988] 1 S.C.R. 401 . The Federal statute was named the "Ocean Dumping Control Act" and its scheme of rules was consistent with the idea of complete control and not simply prohibition. To dump even harmless substances a permit was required. If, on the other hand, the name of the statute had been the "Ocean Dumping Prohibition $A c t^{\prime}$, but the scheme the same, it would appear that inclusive integrity, the rule that purposiveness (scheme) overrules purpose (intention), would require reading "prohibition" as "control". Such word play appears deceptive if the constraint of inclusive integrity on statutory interpretation is not understood. 
Beyond this insight of pure integrity, which reflexively applies to itself the best interpretation of its point, arise further questions. Prominent among them is: what justifies empowering scholars employed at the expense of others - whether the benefactor is public or private - to have the independence from them and everyone else, even from each other, that is appropriate to their scholarly calling?

The short answer is that it depends on the value society has for what counts as true knowledge, in matters of right as well as of fact, and how best to search for it and then to communicate it by teaching and other publication. As long as absolute truth cannot be irrefutably demonstrated, and as long as society finds it better endlessly to search for truth - and for what counts as truth - than to give it up, it will need a company of inquiring scholars. Only inquiring scholars can judge what counts as scholarly research, only scholarly research can qualify one as an inquiring scholar, and only unscholarly research or no research can exclude or expel one from the company of scholars. The fact that the word "university" has packed into it this purposive meaning, when the word is considered merely as a lexical sequence of letters, is purely accidental. It is, however, more in the necessary nature of things that for the sake of communication some combination of letters or sounds has to have that purposiveness packed into it, a purposiveness that necessarily goes beyond the intended purposes even of the people who seek to have a university.

What perhaps is surprising is that not until the 1966 Universities Act were the company of scholars, through their self government in General Faculties Council, given the full right and opportunity not to take orders in their teaching and research, other than from themselves, in discharging the important responsibility academic freedom imposes on them in the public interest. But this should not be surprising. Pure integrity gives no guarantee that its story will ever be told; it only presents that possibility, and presents it, I suggest, only if society has the outlook of moral legality. ${ }^{45}$

etc. - pursues truth, while the professional faculties of theology, law and medicine serve the state or public interest. Although in his time because government was despotic he had to restrain himself from telling all the truth he knew, he implies that philosophy, the recent and inferior faculty, had the natural purpose of critiquing and thus disciplining the other three faculties, particularly the theology faculty - and hence serving as their usher, as it were. The special sense in which Kant understood philosophy thus makes it relevant throughout the modern university. It is his type of philosophy that defends reason, and hence argument, by defining its limits through its pure critique of itself. It is also Kant who developed in a complex analysis the idea of "purposiveness without purpose", which I borrow and put to a use he perhaps would not accept. See J.H. Zammito, The Genesis of Kant's Critique of Judgment (Chicago: The University of Chicago Press, 1992) at $157 \mathrm{ff}$. to Alberta. The usual arrangement is for the university president to make recommendations on appointments, promotions and dismissals without any prior procedure, and then, if possible, to restrict it by a procedure established by collective bargaining between a "unionized" company of scholars and the governing corporate body of the university. Neither the company of scholars, except as servants, nor the president have an effective role in this unionized approach. This arrangement is apparently not prohibited under the present 1980 Universities $A c t$, at least as to dismissal procedures for academic staff, provided the General Faculties Council agrees with the dismissal procedure that is collectively bargained. As to whether the unionized approach generally is appropriate for a company of scholars, see MacKinnon, supra note 41. 


\section{CONCLUSION}

Were Calgarians in 1966 to observe carefully what was then happening in northwest Calgary among the people in the buildings newly named the University of Calgary, they would have found, I suggest, what this story of pure integrity I have only sketched tries to tell. Specifically, they would have found not a college nor a research institute, and if they had, they would likely have been disappointed. Instead, they would have found what they would have understood, at least intuitively, what a university is, a company of scholars engaged in research to find knowledge that counts as true and to teach it to themselves and to their students. Or, at least, they would have found in the scheme and purposiveness of the 1966 Universities Act for the first time that possibility as an unfinishable plain fact of law. 